\title{
EFFECT OF SUPPLEMENTATION OF SOME MEDICAL HERBS OR THEIR EXTRACTS ON THE PERFORMANCE AND PHYSIOLOGICAL FUNCTIONS IN BROILER CHICKENS. 1- CURCUMIN AND ANISE GROUND SEEDS AND INTERACTION EFFECTS ON BROILER CHICKS PERFORMANCE AND SOME BLOOD PARAMETERS
}

\author{
M.A. Metwally ${ }^{1}$; E.M. Nadi ${ }^{2}$ and A.M. El hadi ${ }^{2}$
}

\author{
${ }^{I}$ Dept. of Poultry Production, Faculty of Agriculture, Assiut University, Assiut, Egypt. \\ ${ }^{2}$ Dept. of Animal Production (PoultryDivision), Faculty of Agriculture, Al-Azhar Assiut University. \\ Egypt.
}

(Received 12/5/2021, accepted 9/6/2021)

\section{SUMMARY}

$\mathrm{T}$

The present study was designed to investigate the effect of curcumin, anise seeds levels and their interactions on growth performance and some blood parameters of broiler chicken. Two hundred and ninety seven birds were randomly assigned in $(3 \times 3)$ factorial design. Three curcumin levels $(0,50,100 \mathrm{mg} / \mathrm{kg})$ and three anise ground seeds levels $(0,0.50 \%, 1 \%)$ in nine treatments of 33 birds each (three replicates of 11 birds each) were used. Body weight and feed intake were recorded weekly. Body weight gain and feed conversion were calculated at the end of the experiment (42 day of age). Blood samples were obtained from birds at 21 and 42 day throughout the experiment. The results showed that chickens which were fed curcumin at level of $100 \mathrm{mg} / \mathrm{kg}$ diet achieved higher body weight, body weight gain and feed intake at 42 days of age compared to the control and level of $50 \mathrm{mg} / \mathrm{kg}$ diet. Also, the addition of anise ground seeds achieved higher body weight, body weight gain and feed intake at 42 days of age compared to the control. No significant $(\mathrm{P}<0.05)$ effects on feed conversion ratio were observed due to curcumin, anise ground seeds and their interactions. There were significant $(\mathrm{P}<0.05)$ effect due to curcumin levels on cholesterol, LDL at 42 day. Also, There were significant $(P<0.05)$ effect due to interactions of curcumin and anises seeds levels on HDL at 21 day and total protein, albumin, calcium cholesterol and LDL at 42 day of age. It was recommended that curcumin should be add at level of 100 or $50 \mathrm{mg} / \mathrm{kg}$ diet plus $1 \%$ anise ground seeds to achieve the best results of growth performance and blood parameters of broiler chicken (Ross 308).

Keywords: Broilers, Curcumin, Anise seeds, performance and blood.

\section{INTRODUCTION}

Medicinal plants have become of great importance due to their role in enhancing the body's immunity against many microbes and acting as a catalyst for the digestive process in the digestive system of animals (Tipu et al., 2002). Medicinal herbs contain compounds of great benefits and importance due to their physiological effect and therapeutic activity on humans and animals) Motlaq and Sadik, 2012). Among these medicinal plants are turmeric (Curcuma longa) and anise seeds (Pimpinella anisum) Curcumin is the main component extracted from the turmeric longa plant (Khan et al., 2012). Curcumin 


\section{Metwally et al.}

has been recognized as a major biologically active ingredient in turmeric withnumerous effects including antimicrobial, anti-inflammatory, antioxidant, antiproliferative, antiarthritic and neuroprotective activities (Prasad et al., 2014). Dalal and Kosti (2018) reported that Phenolic compounds administration like curcumin may reduce gut inflammation, improve digestibility of nutrients and metabolism. Improved total protein of blood was observed in 5week old broiler chickens (Ross 308) fed diets containing curcumin $(50,100 \mathrm{mg} / \mathrm{kg})$ compared to the control, while no significant effect on blood total protein when chicks fed diets containing curcumin $(25 \mathrm{mg} / \mathrm{kg}$ ) compared to the control (Badran et al., 2020). Gabriela et al. (2020) found decrease in body weight and body weight gain in 5 week old broiler chickens (Ross 308) fed diets containing curcumin (100 mg / kg) compared to the control. Amein et al. (2019) reported the increase in total protein, cholesterol, albumin, globulin in blood of 42 day old broiler chickens (Ross308) fed diets containing turmeric (0.3\%) compared to the control.

Anise seeds are an aromatic annual herbal plant native to the Middle East, and Egypt is one of the most productive Arab countries. It uses dry fruits and the oil extracted from them, are used. The dry fruits contain 2-6\% aromatic oils, the most important of which are anethole $80-90 \%$, estragole $2 \%$, anis aldehyde $1 \%$, inalol, alpha-terpineol, It works as a general stimulant, appetite stimulant, anti-fungi, antibacteria and virus repellant, gas repellent, and respiratory system disease treatment (ACSAD, 2012). Anise seeds contains many effective compounds, the most important of which is anethole, anisaldehyde, methylchvicol and is considered anti-fungal, hypothermic, anti-viral, anti-bacterial, and anti-oxidant (Cifftci et al., 2005). Amein et al. (2019) found that an improved body weight and body weight gain was observed in 6week old broiler chickens fed diets containing anise seeds $(0.3 \%, 0.6 \%)$ compared to the control birds. Mohammed (2019) reported that an improved body weight and body weight gain was observed in 6 week old broiler chickens fed diets containing anise seeds $(0.3 \%, 0.6 \%$, $0.9 \%$ ) compared to the control. An increase of blood albumin and globulin was observed in 6 week old broiler chickens (Hubbard) fed diets containing anise seeds $(50,150 \mathrm{mg} / \mathrm{kg}$ ) compared to the control (AL-Zuhairi et al., 2013).Therefore, this study was conducted to investigate the effect of curcuminand anise ground seeds and their interactions on growth performance, and blood parameters, of broiler chickens.

\section{MATERIALS AND METHODS}

This study was conducted at commercial farm for broiler located in Senbellawein city-DakahliaEgypt between September 2020 and October 2020. A total number of 297 (two hundred ninety seven) unsexed Ross 308 broiler chicks at one day-old, were individually weighed. Consequently, chicks were equally distributed into 9 treatments with average body weight $(45.02 \pm 1.07 \mathrm{~g})$ and total number (33 chicks/ treatment), each treatment was further divided into 3 replicates (11 chicks each).All diets were formulated to meet or exceed (NRC, 1994) recommendations for essential amino acids in starter diet from day one to 21 days old of age (Table 1) and grower diet from 22 days to 42day (Table 2). Chicks were housed in floor pens $(1 \times 1.5 \mathrm{~m})$ and brooded throughout the experimental period on a Sawdust litter $(5-7 \mathrm{~cm})$. The chicks were reared under $32^{\circ} \mathrm{C}$ temperature as standard brooding temperature and $60 \%$ relative humidity during the first week, then gradually reduced $2^{\circ} \mathrm{C}$ every three days to reach $24^{\circ} \mathrm{C}$ and $55 \%$ relative humidity. A factorial design $(3 \times 3)$ was applied using used. Three levels of curcumin (control, 50 and $100 \mathrm{mg} / \mathrm{kg}$ ) and three levels of ground anise (control, 0.5 and $1 \%$ ).

\section{Feed analysis:}

Dry matter, crude protein, crude fiber, ash, ether extract were estimated in the feed by Dakahlia Poultry company - Damas - Egypt using the device of NIRS ${ }^{\mathrm{TM}}$ DS2500FA.Also, total calcium and total phosphorous in the feed was chemically estimated well following the standard methods of analysis described by the Association of Official Analytical Chemists (AOAC, 1990) in the Animal Production Laboratory, Faculty of Agriculture, Al-Azhar University, Assiut, Egypt. 
Egyptian J. Nutrition and Feeds (2021)

Table (1): Ingredients and composition of the starter experimental diets (1-21d).

\begin{tabular}{|c|c|c|c|c|c|c|c|c|c|}
\hline \multirow{2}{*}{ Item } & \multicolumn{9}{|c|}{ Groups } \\
\hline & $\mathrm{T} 1$ & $\mathrm{~T} 2$ & $\mathrm{~T} 3$ & $\mathrm{~T} 4$ & $\mathrm{~T} 5$ & T6 & $\mathrm{T} 7$ & T8 & T9 \\
\hline \multicolumn{10}{|c|}{ Physical composition\%: } \\
\hline Anise seeds $\%$ & 0 & 0.5 & 1 & 0 & 0.5 & 1 & 0 & 0.5 & 1 \\
\hline Curcumin(Mg/Kg) & 0 & 0 & 0 & 50 & 50 & 50 & 100 & 100 & 100 \\
\hline Yellow corn $\%$ & 54.30 & 54.20 & 54.20 & 54.30 & 54.20 & 54.20 & 54.30 & 54.20 & 54.20 \\
\hline $\begin{array}{l}\text { Soy bean meal } \\
(46) \%\end{array}$ & 36.99 & 36.79 & 36.79 & 36.99 & 36.79 & 36.79 & 36.99 & 36.79 & 36.79 \\
\hline Sunflower oil\% & 4.90 & 4.70 & 4.50 & 4.90 & 4.70 & 4.50 & 4.90 & 4.70 & 4.50 \\
\hline Di-Ca phosphate $\%$ & 1.73 & 1.73 & 1.53 & 1.73 & 1.73 & 1.53 & 1.73 & 1.73 & 1.53 \\
\hline Lime stone $\%$ & 1.33 & 1.33 & 1.23 & 1.33 & 1.33 & 1.23 & 1.33 & 1.33 & 1.23 \\
\hline DL-Methionine $\%$ & 0.15 & 0.15 & 0.15 & 0.15 & 0.15 & 0.15 & 0.15 & 0.15 & 0.15 \\
\hline Premix \%* & 0.30 & 0.30 & 0.30 & 0.30 & 0.30 & 0.30 & 0.30 & 0.30 & 0.30 \\
\hline Common salt $\%$ & 0.30 & 0.30 & 0.30 & 0.30 & 0.30 & 0.30 & 0.30 & 0.30 & 0.30 \\
\hline Total\% & 100.00 & 100.00 & 100.00 & 100.00 & 100.00 & 100.00 & 100.00 & 100.00 & 100.00 \\
\hline \multicolumn{10}{|c|}{ Chemical composition $(\%)$ : } \\
\hline Dry matter\% & 88.84 & 88.64 & 88.40 & 88.62 & 88.50 & 88.56 & 88.37 & 88.61 & 88.64 \\
\hline $\mathrm{ME}, \mathrm{Kcal} / \mathrm{kg} \mathrm{DM}$ & 3187 & 3198 & 3189 & 3155 & 3159 & 3190 & 3172 & 3151 & 3212 \\
\hline Crude protein $\%$ & 22.66 & 22.72 & 22.47 & 22.18 & 22.23 & 22.40 & 22.54 & 22.43 & 22.23 \\
\hline Ether extract\% & 7.24 & 7.59 & 7.38 & 7.22 & 6.77 & 7.27 & 7.34 & 6.91 & 7.77 \\
\hline Crude fiber\% & 2.61 & 2.46 & 2.25 & 3.19 & 2.44 & 2.25 & 2.57 & 3.12 & 2.42 \\
\hline NFE\% & 50.35 & 49.79 & 50.28 & 50 & 51.08 & 50.63 & 49.81 & 50.33 & 50.29 \\
\hline Ash\% & 5.98 & 6.08 & 6.02 & 6.03 & 5.98 & 6.01 & 6.11 & 5.82 & 5.93 \\
\hline Calcium\% & 1.06 & 1.22 & 1.06 & 1.30 & 1.22 & 1.30 & 0.89 & 1.14 & 1.14 \\
\hline $\begin{array}{l}\text { Total } \\
\text { phosphorus\% }\end{array}$ & 0.60 & 0.59 & 0.53 & 0.60 & 0.72 & 0.60 & 0.51 & 0.66 & 0.57 \\
\hline \multicolumn{10}{|c|}{ Calculated composition (\%) } \\
\hline $\mathrm{ME}, \mathrm{Kcal} / \mathrm{kg} \mathrm{DM}$ & 3158 & 3133 & 3116 & 3158 & 3133 & 3116 & 3158 & 3133 & 3116 \\
\hline Crude protein $\%$ & 21.50 & 21.40 & 21.40 & 21.50 & 21.40 & 21.40 & 21.50 & 21.40 & 21.40 \\
\hline Ether extract $\%$ & 4.03 & 4.02 & 4.02 & 4.03 & 4.02 & 4.02 & 4.03 & 4.02 & 4.02 \\
\hline Crude fiber\% & 3.84 & 3.82 & 3.82 & 3.84 & 3.82 & 3.82 & 3.84 & 3.82 & 3.82 \\
\hline Ash\% & 3.11 & 3.10 & 3.10 & 3.11 & 3.10 & 3.10 & 3.11 & 3.10 & 3.10 \\
\hline Calcium\% & 1.00 & 1.00 & 0.91 & 1.00 & 1.00 & 0.91 & 1.00 & 1.00 & 0.91 \\
\hline $\begin{array}{l}\text { Total } \\
\text { phosphorus\% }\end{array}$ & 0.72 & 0.71 & 0.68 & 0.72 & 0.71 & 0.68 & 0.72 & 0.71 & 0.68 \\
\hline Av phosphorus $\%$ & 0.42 & 0.42 & 0.39 & 0.42 & 0.42 & 0.39 & 0.42 & 0.42 & 0.39 \\
\hline Lysine\% & 1.24 & 1.23 & 1.23 & 1.24 & 1.23 & 1.23 & 1.24 & 1.23 & 1.23 \\
\hline Methionine\% & 0.53 & 0.53 & 0.53 & 0.53 & 0.53 & 0.53 & 0.53 & 0.53 & 0.53 \\
\hline \multicolumn{10}{|c|}{$\begin{array}{l}\text { 'Each } 3 \mathrm{~kg} \text { of vitamin mineral premix: contains: vitamin A, } 1200000 I U \text {; vitamin D3, 300000IU; vitamin E,700 mg; } \\
\text { vitamin } \mathrm{K} 3,500 \mathrm{mg} \text {; vitamin B1 } 500 \mathrm{mg} \text {; vitamin B2 } 200 \mathrm{mg} \text {; vitamin B6, } 600 \mathrm{mg} \text {, vitamin B12, } 3 \mathrm{mg} \text {; folic acid, } 300 \\
\mathrm{mg} \text {; choline chloride, } 1000 \mathrm{mg} \text {; Niacin, } 3000 \mathrm{mg} \text {; Methionine } 3000 \mathrm{mg} \text {; Biotin } 6 \mathrm{mg} \text {; panathonic acid } 670 \mathrm{mg} \text {; } \\
\text { manganese sulphate, } 3000 \mathrm{mg} \text {; iron sulphate, } 10000 \mathrm{mg} \text {, zinc sulphate, } 1800 \mathrm{mg} \text {, copper sulphate } 3000 \mathrm{mg} \text {, iodine } \\
1.868 \mathrm{mg} \text {, cobalt sulphate, } 300 \mathrm{mg} \text {; selenium, } 0.108 \mathrm{mg} \text {. }\end{array}$} \\
\hline
\end{tabular}

\section{Criteria studied:}

\section{Body weight, body weight gain, feed consumption and feed conversion ratio:}

Body weights were recorded individually at one-day and 42 day of age. Feed consumption was also recorded and calculated as gram feed/bird/day for the same time periods. Body weight gains (BWG) were calculated at (1-42) days of age. Feed conversion ratio (FCR) were also calculated during the same previous period of the experiment (1-42 days of age). 


\section{Blood sampling:}

Approximately $4.0 \mathrm{ml}$ of blood was collected from the brachial vein of chicks at 21 and 42 day in tubes (half of them were placed in tubes containing an anticoagulant, the remainder in tubes without anticoagulant. Blood samples were centrifuged at 3,000 rpm for $15 \mathrm{~min}$, and serum obtained was stored at $-20{ }^{\circ} \mathrm{C}$ until analysis. Serum total protein, albumin and globulin values were obtained by subtracting the values of albumin from the corresponding values of total protein, Cholesterol, triglycerides, total calcium and phosphorus, uric acid and some transaminase enzymes activities (Aspartate aminotransferase (AST) and alanine aminotransferase (ALT) were determined calorimetrically using available commercial kits purchased from Spectrum Diagnostic Company (Cairo, Egypt).

Table (2): Ingredients and chemical composition of the grower finisher diets (22-42d).

\begin{tabular}{|c|c|c|c|c|c|c|c|c|c|}
\hline \multirow{2}{*}{ Item } & \multicolumn{9}{|c|}{ Groups } \\
\hline & $\mathrm{T} 1$ & $\mathrm{~T} 2$ & T3 & $\mathrm{T} 4$ & $\mathrm{~T} 5$ & T6 & T7 & T8 & T9 \\
\hline \multicolumn{10}{|l|}{ Physical composition\%: } \\
\hline Anise seeds $\%$ & 0 & 0.5 & 1 & 0 & 0.5 & 1 & 0 & 0.5 & 1 \\
\hline Curcumin(Mg/Kg) & 0 & 0 & 0 & 50 & 50 & 50 & 100 & 100 & 100 \\
\hline Yellow corn $\%$ & 61.50 & 61.40 & 61.40 & 61.50 & 61.40 & 61.40 & 61.50 & 61.40 & 61.40 \\
\hline Soy bean meal (46)\% & 29.75 & 29.55 & 29.55 & 29.75 & 29.55 & 29.55 & 29.75 & 29.55 & 29.55 \\
\hline Sunflower oil\% & 4.90 & 4.70 & 4.50 & 4.90 & 4.70 & 4.50 & 4.90 & 4.70 & 4.50 \\
\hline Di-Ca phosphate $\%$ & 1.72 & 1.72 & 1.52 & 1.72 & 1.72 & 1.52 & 1.72 & 1.72 & 1.52 \\
\hline Lime stone $\%$ & 1.33 & 1.33 & 1.23 & 1.33 & 1.33 & 1.23 & 1.33 & 1.33 & 1.23 \\
\hline DL-Methionine $\%$ & 0.20 & 0.20 & 0.20 & 0.20 & 0.20 & 0.20 & 0.20 & 0.20 & 0.20 \\
\hline Premix \%* & 0.30 & 0.30 & 0.30 & 0.30 & 0.30 & 0.30 & 0.30 & 0.30 & 0.30 \\
\hline Common salt\% & 0.30 & 0.30 & 0.30 & 0.30 & 0.30 & 0.30 & 0.30 & 0.30 & 0.30 \\
\hline Total\% & 100.00 & 100.00 & 100.00 & 100.00 & 100.00 & 100.00 & 100.00 & 100.00 & 100.00 \\
\hline \multicolumn{10}{|c|}{ Chemical composition (\%): } \\
\hline Dry matter\% & 88.54 & 88.44 & 88.10 & 88.41 & 88.79 & 88.84 & 88.53 & 88.33 & 88.31 \\
\hline $\mathrm{ME}, \mathrm{Kcal} / \mathrm{kg} \mathrm{DM}$ & 3182 & 3212 & 3137 & 3153 & 3222 & 3219 & 3172 & 3204 & 3192 \\
\hline Crude protein $\%$ & 19.61 & 19.07 & 18.89 & 19.36 & 18.74 & 18.83 & 18.47 & 18.74 & 19.20 \\
\hline Ether extract\% & 7.53 & 7.76 & 7.19 & 6.96 & 7.62 & 7.79 & 7.02 & 7.98 & 7.52 \\
\hline Crude fiber\% & 2.53 & 2.08 & 2.92 & 2.49 & 2.03 & 2.46 & 2.24 & 2.05 & 2.02 \\
\hline NFE $\%$ & 52.76 & 53.65 & 53.01 & 53.52 & 54.6 & 54.05 & 54.86 & 53.25 & 53.5 \\
\hline Ash\% & 6.11 & 5.88 & 6.09 & 6.08 & 5.80 & 5.71 & 5.94 & 6.31 & 6.07 \\
\hline Calcium\% & 1.38 & 1.22 & 1.14 & 1.22 & 1.06 & 1.22 & 1.30 & 0.89 & 1.06 \\
\hline Total phosphorus $\%$ & 0.60 & 0.56 & 0.55 & 0.58 & 0.54 & 0.58 & 0.66 & 0.58 & 0.62 \\
\hline \multicolumn{10}{|c|}{ Calculated composition $(\%)$ : } \\
\hline $\mathrm{ME}, \mathrm{Kcal} / \mathrm{kg} \mathrm{DM}$ & 3252 & 3227 & 3211 & 3252 & 3227 & 3211 & 3252 & 3227 & 3211 \\
\hline Crude protein $\%$ & 18.78 & 18.68 & 18.68 & 18.78 & 18.68 & 18.68 & 18.78 & 18.68 & 18.68 \\
\hline Ether extract \% & 4.38 & 4.37 & 4.37 & 4.38 & 4.37 & 4.37 & 4.38 & 4.37 & 4.37 \\
\hline Crude fiber \% & 3.46 & 3.45 & 3.45 & 3.46 & 3.45 & 3.45 & 3.46 & 3.45 & 3.45 \\
\hline Ash \% & 2.73 & 2.72 & 2.72 & 2.73 & 2.72 & 2.72 & 2.73 & 2.72 & 2.72 \\
\hline Calcium\% & 0.97 & 0.97 & 0.89 & 0.97 & 0.97 & 0.89 & 0.97 & 0.97 & 0.89 \\
\hline Total phosphorus $\%$ & 0.69 & 0.69 & 0.65 & 0.69 & 0.69 & 0.65 & 0.69 & 0.69 & 0.65 \\
\hline Av phosphorus $\%$ & 0.40 & 0.40 & 0.36 & 0.40 & 0.40 & 0.36 & 0.40 & 0.40 & 0.36 \\
\hline Lysine \% & 1.04 & 1.04 & 1.04 & 1.04 & 1.04 & 1.04 & 1.04 & 1.04 & 1.04 \\
\hline Methionine \% & 0.55 & 0.55 & 0.55 & 0.55 & 0.55 & 0.55 & 0.55 & 0.55 & 0.55 \\
\hline
\end{tabular}

*Each $3 \mathrm{~kg}$ of vitamin mineral premix: contains: vitamin A, 1200000IU; vitamin D3, 300000IU; vitamin E,700 mg; vitamin K3, $500 \mathrm{mg}$; vitamin B1 $500 \mathrm{mg}$; vitamin B2 $200 \mathrm{mg}$; vitamin B6, $600 \mathrm{mg}$, vitamin B12, $3 \mathrm{mg}$; folic acid, 300 mg; choline chloride, 1000 mg; Niacin, 3000 mg; Methionine 3000 mg; Biotin 6 mg; panathonic acid 670 mg; manganese sulphate, $3000 \mathrm{mg}$; iron sulphate, $10000 \mathrm{mg}$, zinc sulphate, $1800 \mathrm{mg}$, copper sulphate $3000 \mathrm{mg}$, iodine $1.868 \mathrm{mg}$, cobalt sulphate, $300 \mathrm{mg}$; selenium, $0.108 \mathrm{mg}$. 


\section{Statistical analysis:}

Data obtained from this study were tested for the factorial design $(3 \times 3)$ by ANOVA and GLM using the SAS procedure (2006). Duncan's multiple range tests (1955) was also used to determine differences among means when treatment effects were significant. Significant differences were considered to exist when $(P<0.05)$.

The statistical model used as following:

Where;

$$
\text { Yijk }=\mu+\text { Curi }+ \text { Anisj }+(\text { Cur*Anis }) i j+\text { Eijk }
$$

Yijk = An observation of traits.

$\mu=$ The overall mean.

Curi= The fixed effect of; th curcumin (where $i=1,2$ and 3).

Anisj= The fixed effect of; th anise (where $\mathrm{j}=1,2$ and 3).

(Cur*Anis) $\mathrm{ij}=$ Interaction of Curcumin levels $\times$ Anis percentages

Eijk= Experimental random error.

\section{RESULTS AND DISCUSSION}

Effects of curcumin, anise seeds levels and their interactions on:

Body weight (BW), body weight gains (BWG), feed intake (FI) and feed conversion ratio (FCR):

Effects of curcumin, anise ground seeds levels and their interactions on body weight of Ross 308 broiler chicks are presented in Table3.The results showed that there were no significant $(\mathrm{P}<0.05)$ effects of curcumin on BW, BWG, FI and FCR at 42 days of age. Our results are in agreement with Gabriela et al. (2020) who found that no significant differences were observed on BW, BWG and FCR at 42 days of age of broiler chickens fed diets containing curcumin (100 mg / kg) compared to the control. This connection, Badran et al. (2020) reported that there were no significant differences on BW, BWG and FCR when feeding chicks with diets fed containing curcumin ( $25 \mathrm{mg} / \mathrm{kg}$ ) compared to the control group at (1-35) days of age. Moreover, Xie et al. (2019) found that there was no significant effect on BW, FI and FCR when feeding chicks with diets containing curcumin $(500 \mathrm{mg} / \mathrm{kg}$ ) compared to the control at age of (22-49) days. Candra and Putri (2020) indicated no significant effect on FI when feeding chicks with diets containing turmeric $(500 \mathrm{mg} / \mathrm{kg}$ ) compared to the control at age 30 days of age .On the other hand, the obtained results are in disagreement with Rajput et al. (2012) whoreported that BWG was in birds at (0-42) days of age of broiler chickens fed diets containing curcumin improved significantly $(100,150,200 \mathrm{mg} / \mathrm{kg})$ compared to the control group and the best one was $200 \mathrm{mg} / \mathrm{kg}$. Badran et al. (2020) found significant improvement in BW and BWG in broilers (1-35 days) fed diets containing curcumin $(50,100 \mathrm{mg} / \mathrm{kg})$ compared with the control group. However, numerically improve in body weight and body weight gain red been found in birds fed diets containing the third level of curcumin $(100 \mathrm{mg} / \mathrm{kg})$ when compared with the control and the second level $(50 \mathrm{mg} / \mathrm{kg})$ of curcumin.

Regarding to the effect of anise ground seeds levels and their interactions there were no significant $(\mathrm{P}<0.05)$ differences on BW, BWG, FI and FCR at 42 days of age. Our results are in agreement with (Barakat et al., 2016 ) who reported that there were no significant effect on body and body weight gain at 5 weeks old of broiler chickens (Cobb) fed diets containing anise seeds $(0.5,0.75 \mathrm{gm} / \mathrm{kg})$ compared to the control. Also, Amein et al. (2019) indicated that there was no significant effect on feed intake in birds (0-6) week old broiler chickens (Ross 308$)$ fed diets containing anise seeds $(0.3 \%, 0.6 \%)$ compared to the control. No significant difference were abo observed on conversion ratio when feeding chicks with diets containing anise seeds $(0.2 \%, 4 \%, 0.6 \%)$ compared to control (7-35) day at age (Mahmod, 2013). On the other hand, the obtained results are in disagreement with Amein et al. (2019) who reported an improve in body weight and body weight gain in birds at 42 days of broiler chickens fed diets containing anise seeds. Also Jabber et al. (2015) found an improve in feed intake 6 weeks old broiler chickens (Ross308) fed diets containing anise seeds $(2,4,6,8 \mathrm{~kg} / \mathrm{ton})$ compared to the control . 


\section{Metwally et al.}

However, numerically improve in body weight, body weight gain and feed intake of birds fed on diets containing anise seeds) $0.5 \%, 1 \%$ diet) when compared with the control. Continuous use of antibiotics in poultry diets has evoked numerous problems such as cross-resistance and environmental pollution. So that, the search for alternative growth promoting substances to replace classical antibiotics in poultry diets has to be continued. Therefore, vegetables, herbs, spices and edible plants were suggested as nontraditional feed additives in animal nutrition. This unnoticeable improvement in LBW at the whole experimental period (1-6 wks of age) might be due to non-improved digestion and absorption of diet nutrients by some components of the phytogenic additives (Tables 3). However, that may be contributed to non-enhancing the utilization of feed consequence, non-enhancing the growth rate. Prohibition of used antibiotics in poultry production due to a widely used of herbs and plant medicines as feed additives to improve growth condition, its induced saliva secretion and improve digestion processes (Suganya et al., 2016). Phytogenic additives may also reduce the environmental problems dangerous that are produced by using antibiotics as feed additives such as bacterial resistance (Perić et al., 2009). Fotina et al. (2013) reported that to preserve broiler growth rate, quality of meat and immune responses, and its necessary added optimal antioxidant level to diets.

Table (3): Effects of curcumin and anise ground seeds and their interactions on growth performance (g/bird) of broiler chickens.

\begin{tabular}{|c|c|c|c|c|c|}
\hline \multirow[b]{2}{*}{ Age/ Day } & \multicolumn{2}{|c|}{ Body weight } & \multirow{2}{*}{$\begin{array}{l}\text { Body weight } \\
\text { gain (0-42 day) }\end{array}$} & \multirow{2}{*}{$\begin{array}{l}\text { Feed intake } \\
(0-42) \text { day })\end{array}$} & \multirow{2}{*}{$\begin{array}{c}\text { Fed } \\
\text { conversion } \\
\text { ratio }(0-42 \\
\text { day) } \\
\end{array}$} \\
\hline & One day & 42 day & & & \\
\hline \multicolumn{6}{|l|}{ Curcumin (mg /Kg): } \\
\hline 0 & $44.98 \pm 0.09$ & $2446.67 \pm 43.48$ & $2401.68 \pm 43.49$ & $3873.81 \pm 67.83$ & $1.614 \pm 0.014$ \\
\hline 50 & $44.88 \pm 0.11$ & $2442.49 \pm 63.57$ & $2397.62 \pm 63.57$ & $3935.88 \pm 55.69$ & $1.647 \pm 0.025$ \\
\hline 100 & $45.19 \pm 0.11$ & $2483.84 \pm 38.50$ & $2438.65 \pm 38.48$ & $3943.05 \pm 49.68$ & $1.618 \pm 0.017$ \\
\hline \multicolumn{6}{|l|}{ Anise seeds $\%:$} \\
\hline 0 & $44.97 \pm 0.12$ & $2440.89 \pm 70.28$ & $2395.92 \pm 70.23$ & $3866.58 \pm 64.39$ & $1.614 \pm 0.029$ \\
\hline 0.50 & $45.01 \pm 0.09$ & $2467.88 \pm 35.72$ & $2422.87 \pm 35.72$ & $3914.80 \pm 61.19$ & $1.616 \pm 0.010$ \\
\hline 1 & $45.07 \pm 0.13$ & $2464.23 \pm 35.70$ & $2419.16 \pm 35.75$ & $3971.36 \pm 44.21$ & $1.643 \pm 0.014$ \\
\hline \multicolumn{6}{|l|}{ Interactions: } \\
\hline $\mathrm{T} 1(0 \mathrm{Cu} \times 0 \mathrm{An})$ & $45.12 \pm 0.21$ & $2413.60 \pm 92.82$ & $2368.52 \pm 92.70$ & $3811.34 \pm 105.02$ & $1.612 \pm 0.044$ \\
\hline $\mathrm{T} 2(0 \mathrm{Cu} \times 0.5 \% \mathrm{An})$ & $44.97 \pm 0.11$ & $2461.21 \pm 104.77$ & $2416.24 \pm 104.87$ & $3877.21 \pm 196.23$ & $1.604 \pm 0.012$ \\
\hline $\mathrm{T} 3(0 \mathrm{Cu} \times 1 \% \mathrm{An})$ & $44.85 \pm 0.15$ & $2465.15 \pm 47.63$ & $2420.30 \pm 47.74$ & $3932.88 \pm 44.46$ & $1.626 \pm 0.016$ \\
\hline $\mathrm{T} 4$ (50 Cu×0An) & $44.73 \pm 0.11$ & $2434.79 \pm 203.88$ & $2390.06 \pm 203.79$ & $3915.18 \pm 155.21$ & $1.652 \pm 0.084$ \\
\hline T5 (50 Cu×0.5\%An) & $45.03 \pm 0.23$ & $2430.30 \pm 37.51$ & $2385.27 \pm 37.29$ & $3899.27 \pm 62.54$ & $1.635 \pm 0.020$ \\
\hline T6 (50 Cu×1\%An) & $44.88 \pm 0.22$ & $2462.39 \pm 72.26$ & $2417.52 \pm 72.44$ & $3993.18 \pm 81.79$ & $1.653 \pm 0.017$ \\
\hline $\mathrm{T} 7(100 \mathrm{Cu} \times 0 \mathrm{An})$ & $45.06 \pm 0.26$ & $2474.24 \pm 90.24$ & $2429.18 \pm 90.12$ & $3873.21 \pm 109.10$ & $1.596 \pm 0.022$ \\
\hline $\mathrm{T} 8(100 \mathrm{Cu} \times 0.5 \% \mathrm{An})$ & $45.03 \pm 0.16$ & $2512.12 \pm 34.95$ & $2467.09 \pm 34.83$ & $3967.91 \pm 16.61$ & $1.609 \pm 0.018$ \\
\hline T9 (100 Cu×1\%An) & $45.48 \pm 0.03$ & $2465.15 \pm 88.31$ & $2419.67 \pm 88.34$ & $3988.03 \pm 116.95$ & $1.650 \pm 0.041$ \\
\hline
\end{tabular}

*T1 control(zero of curcumin or anise seeds),T2(zero of curcumin and 0.5\% anise seeds),T3(zero of curcumin and $1 \%$ anise seeds),T4(50mg $/ \mathrm{kg}$ curcumin and zero anise seeds),T5(50 mg $/ \mathrm{kg}$ curcumin and 0.5\%anise seeds),T6(50 $\mathrm{mg} / \mathrm{kg}$ curcumin and 1\%anise seeds),T7(100mg $/ \mathrm{kg}$ curcumin and zero anise seeds),T8(100mg $/ \mathrm{kg}$ curcumin and $0.5 \%$ anise seeds),T9 (100mg $/ \mathrm{kg}$ curcumin and $1 \%$ anise seeds).

\section{Blood parameters:}

\section{At 21 days of age:}

The effect of curcumin, anise ground seeds level and their interactions on total protein, albumin, globulin, total calcium and phosphorus, uric acid, cholesterol, HDL, LDL, triglycerides, AST and ALT are presented in Table 4. The results showed that there were no significant $(\mathrm{P}<0.05)$ effect of either curcumin or anise ground seeds alone on all the previous parameters. Also, no significant $(\mathrm{P}<0.05)$ difference due to interactions between curcumin and anise ground seeds on the previous parameters except HDL and HDL/LDL. However, broiler chickens fed diets contained $100 \mathrm{mg} / \mathrm{kg}$ curcumin only achieved higher serum HDL and HDL/LDL by about $(79.71 \%)$ and (168.75\%) than those fed control 
diet, respectively. Our results are in agreement with Qasem et al. (2016) who reported that no significant effect was observed at 21 day on total protein, albumin, globulin and alanine aminotransferase (ALT) in birds at 21 days of age of broiler chickens fed diets containing turmeric compared to control.

\section{At 42 days of age:}

The effect of curcumin, anise ground seeds levels and their interactions on total protein, albumin, globulin, total calcium and phosphorus, uric acid, cholesterol, HDL, LDL, triglycerides, AST and ALT are presented in Table 5. The results showed that ther were no significant $(\mathrm{P}<0.05)$ effect of either curcumin or anise ground seeds on all the previous parameters except for curcumin effect on cholesterol, LDL and HDL/LDL. However, birds fed diets containing curcumin (50 and $100 \mathrm{mg} / \mathrm{kg}$ ) achieved a lower level of blood cholesterol and a lower level of harmful LDL cholesterol compared to controls. Our results are in agreement with Gabriela et al. (2020) who reported that no significant effect was observed on total protein, globulin, uric acid, triglycerides when feeding chicks diets containing curcumin. Also, Badran et al. (2020) reported that there was no significant effect on albumin, albumin/globulin, alanine aminotransferase (ALT) when birds fed diets with curcumin at $(25,50,100 \mathrm{mg} / \mathrm{kg}$ ), also no significant effect on high-density lipoprotein cholesterol (HDL) when chicks fed diets containing curcumin $(25 \mathrm{mg} /$ $\mathrm{kg}$ ). Also, There was no significant effect on total protein ,cholesterol ,cholesterol LDL and triglycerides when feeding chicks with diets containing anise seeds $(0.25,0.50,0.75,1,1.25,1.5 \mathrm{gm} / \mathrm{kg})$ compared to control (Soltan et al., 2008). Amein et al. (2019) did not eind no significant effect on uric acid, calcium and phosphorous in broilers at 6 weeks of age (Ross 308) in broilers fed diets containing anise seeds $(0.3 \%, 0.6 \%)$ compared to control chickens.

The results of interactions between curcumin and anise ground seeds showed that there were no significant $(\mathrm{P}<0.05)$ difference in the previous parameters except total protein, albumin, calcium, cholesterol, LDL. However, broiler chickens fed diets contained $0.5 \%$ anise ground seeds achieved higher serum calcium, total cholesterol, LDL by about $23.05 \%, 36.39 \%$ and $19.76 \%$ than birds fed control diet, respectively. Also, bird fed $0.5 \%$ anise ground seeds was lower in total protein and albumin by about $4.28 \%$ and $8.33 \%$ than birds fed control diet, respectively.

In general, there was no significant effect on calcium, phosphorus when feeding chicks with diets containing curcuma ( $0.3 \%, 0.5 \%)$ compared to the control at 42 days of age (Amein et al., 2019).The inclusion of curcumin in the diet of broilers had resulted in significant $(P<0.05)$ decreases in the serum levels of cholesterol and LDL. Additionally, sodium curcumin ate, a salt of curcumin, was found to exert choleretic effects by increasing biliary excretion of bile salts, cholesterol, and bilirubin, as well as increasing bile solubility. Curcumin helps liver cells continue to do their work of taking LDL "bad" cholesterol out of the bloodstream, but without taking in other fatty acids that "burn out" the mitochondria of the cell. Liver cells protected from fatty acid damage make the liver produce more bile salts, which carry excess LDL out of the body into the waste matter of the large intestine. Hence, curcumin possibly stops the progress of fatty liver and enhances cardiovascular health (Kang et al., 2010). Lower content of cholesterol may result from high body activity and high need of energy in broiler chickens. Significant $(\mathrm{P}<0.05)$ serum cholesterol content of chicks having curcumin in the present study is within the range of $112.10-112.80 \mathrm{mg} / \mathrm{dl}$ as reported by (Albokhadaim et al., 2012). 
Egyptian J. Nutrition and Feeds (2021)

Table (4): Effect of curcumin and anise ground seed and their interactions on some blood parameters measured at age of $21 \mathrm{day}$.

\begin{tabular}{|c|c|c|c|c|c|c|c|}
\hline Item & $\begin{array}{l}\text { Total protein } \\
(\mathrm{g} / \mathrm{dI})\end{array}$ & $\begin{array}{l}\text { Albumin } \\
\text { (g/dI) }\end{array}$ & $\begin{array}{l}\text { Globulin } \\
\text { (g/dI) }\end{array}$ & $\mathrm{A} / \mathrm{G}$ & $\begin{array}{l}\text { Calcium } \\
(\mathrm{mg} / \mathrm{dI})\end{array}$ & Phosphorus (mg/dI) & $\begin{array}{l}\text { Uric acid } \\
(\mathrm{mg} / \mathrm{dI})\end{array}$ \\
\hline \multicolumn{8}{|l|}{ Curcumin $(\mathrm{mg} / \mathrm{Kg})$ : } \\
\hline 0 & $2.96 \pm 0.09$ & $2.03 \pm 0.04$ & $0.93 \pm 0.11$ & $2.48 \pm 0.34$ & $10.42 \pm 0.29$ & $4.83 \pm 0.62$ & $7.87 \pm 0.90$ \\
\hline 50 & $3.15 \pm 0.15$ & $2.03 \pm 0.06$ & $1.12 \pm 0.14$ & $2.03 \pm 0.25$ & $10.21 \pm 0.17$ & $4.89 \pm 0.53$ & $7.98 \pm 0.70$ \\
\hline 100 & $3.36 \pm 0.23$ & $2.06 \pm 0.06$ & $1.31 \pm 0.24$ & $2.00 \pm 0.32$ & $10.44 \pm 0.16$ & $4.43 \pm 0.64$ & $8.51 \pm 0.84$ \\
\hline \multicolumn{8}{|l|}{ Anise seeds \%: } \\
\hline 0 & $2.98 \pm 0.89$ & $2.06 \pm 0.04$ & $0.92 \pm 0.08$ & $2.37 \pm 0.21$ & $10.11 \pm 0.22$ & $4.49 \pm 0.53$ & $7.98 \pm 0.55$ \\
\hline 0.5 & $3.31 \pm 0.21$ & $2.01 \pm 0.05$ & $1.31 \pm 0.21$ & $1.95 \pm 0.37$ & $10.56 \pm 0.25$ & $4.46 \pm 0.57$ & $8.22 \pm 1.05$ \\
\hline 1 & $3.17 \pm 0.18$ & $2.04 \pm 0.07$ & $1.13 \pm 0.18$ & $2.19 \pm 0.33$ & $10.41 \pm 0.16$ & $5.21 \pm 0.66$ & $8.16 \pm 0.79$ \\
\hline \multicolumn{8}{|l|}{ Interactions: } \\
\hline $\mathrm{T} 1(0 \mathrm{Cu} \times 0 \mathrm{An})$ & $3.03 \pm 0.15$ & $2.10 \pm 0.010$ & $0.93 \pm 0.22$ & $2.54 \pm 0.64$ & $10.20 \pm 0.68$ & $4.97 \pm 1.07$ & $7.22 \pm 0.59$ \\
\hline $\mathrm{T} 2(0 \mathrm{Cu} \times 0.5 \% \mathrm{An})$ & $2.99 \pm 0.26$ & $2.00 \pm 0.03$ & $0.99 \pm 0.29$ & $2.54 \pm 0.94$ & $10.93 \pm 0.47$ & $4.60 \pm 1.57$ & $8.27 \pm 2.88$ \\
\hline $\mathrm{T} 3(0 \mathrm{Cu} \times 1 \% \mathrm{An})$ & $2.85 \pm 0.04$ & $1.99 \pm 0.09$ & $0.86 \pm 0.08$ & $2.37 \pm 0.32$ & $10.13 \pm 0.38$ & $4.93 \pm 1.00$ & $8.12 \pm 0.82$ \\
\hline $\mathrm{T} 4(50 \mathrm{Cu} \times 0 \mathrm{An})$ & $2.84 \pm 0.01$ & $2.01 \pm 0.03$ & $0.83 \pm 0.02$ & $2.43 \pm 0.09$ & $10.17 \pm 0.17$ & $5.03 \pm 0.39$ & $7.91 \pm 0.20$ \\
\hline T5 (50 Cu×0.5\%An) & $3.55 \pm 0.22$ & $2.01 \pm 0.12$ & $1.54 \pm 0.19$ & $1.35 \pm 0.17$ & $9.90 \pm 0.40$ & $3.40 \pm 0.46$ & $7.29 \pm 0.90$ \\
\hline T6 (50 Cu×1\%An) & $3.06 \pm 0.28$ & $2.07 \pm 0.14$ & $0.99 \pm 0.24$ & $2.32 \pm 0.58$ & $10.57 \pm 0.23$ & $6.23 \pm 0.98$ & $8.73 \pm 2.12$ \\
\hline T7 (100 Cu×0An) & $3.07 \pm 0.24$ & $2.07 \pm 0.07$ & $1.01 \pm 0.17$ & $2.14 \pm 0.28$ & $9.97 \pm 0.24$ & $3.47 \pm 1.12$ & $8.82 \pm 1.61$ \\
\hline T8 $(100 \mathrm{Cu} \times 0.5 \% \mathrm{An})$ & $3.40 \pm 0.56$ & $2.01 \pm 0.11$ & $1.38 \pm 0.59$ & $1.97 \pm 0.61$ & $10.83 \pm 0.19$ & $5.37 \pm 0.52$ & $9.09 \pm 1.08$ \\
\hline T9 (100 Cu×1\%An) & $3.61 \pm 0.41$ & $2.07 \pm 0.17$ & $1.54 \pm 0.46$ & $1.88 \pm 0.88$ & $10.53 \pm 0.19$ & $4.47 \pm 1.57$ & $7.62 \pm 1.42$ \\
\hline
\end{tabular}

*T1 control(zero of curcumin or anise seeds),T2 (zero of curcumin and 0.5\% anise seeds),T3 (zero of curcumin and $1 \%$ anise seeds),T4(50 $\mathrm{mg} / \mathrm{kg}$ curcumin and zero anise seeds),T5(50 $\mathrm{mg} / \mathrm{kg}$

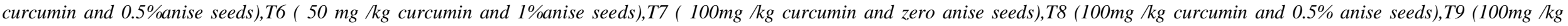
curcumin and $1 \%$ anise seeds). 


\section{Table (4): Cont.}

\begin{tabular}{|c|c|c|c|c|c|c|c|}
\hline Item & $\begin{array}{c}\text { Cholesterol } \\
(\mathrm{mg} / \mathrm{dI})\end{array}$ & $\begin{array}{c}\text { HDL } \\
(\mathrm{mg} / \mathrm{dI})\end{array}$ & $\begin{array}{c}\text { LDL } \\
(\mathrm{mg} / \mathrm{dI})\end{array}$ & HDL/DL & $\begin{array}{c}\text { Triglycerides } \\
(\mathrm{mg} / \mathrm{dI})\end{array}$ & $\begin{array}{l}\text { AST } \\
(\mathrm{u} / \mathrm{l})\end{array}$ & $\begin{array}{l}\text { ALT } \\
(\mathrm{u} / \mathrm{l})\end{array}$ \\
\hline \multicolumn{8}{|l|}{ Curcumin $(\mathrm{mg} / \mathrm{Kg})$ : } \\
\hline 0 & $110.20 \pm 6.7$ & $55.89 \pm 5.45$ & $54.30 \pm 6.3$ & $1.15 \pm 0.1$ & $60.22 \pm 16.6$ & $160.11 \pm 19.7$ & $9.67 \pm 1.8$ \\
\hline 50 & $113.80 \pm 3.9$ & $60.67 \pm 6.01$ & $53.11 \pm 6.8$ & $1.53 \pm 0.4$ & $68.44 \pm 10.0$ & $149.33 \pm 27.0$ & $10.78 \pm 1.4$ \\
\hline 100 & $103.80 \pm 5.5$ & $62.89 \pm 5.25$ & $40.91 \pm 5.0$ & $1.77 \pm 0.2$ & $76.67 \pm 13.6$ & $151.00 \pm 27.7$ & $10.67 \pm 1.7$ \\
\hline \multicolumn{8}{|l|}{ Anise seeds \%: } \\
\hline 0 & $111.10 \pm 6.3$ & $58.44 \pm 7.27$ & $52.63 \pm 8.6$ & $1.48 \pm 0.3$ & $58.22 \pm 9.93$ & $184.22 \pm 24.1$ & $9.11 \pm 1.15$ \\
\hline 0.5 & $111.40 \pm 4.7$ & $63.56 \pm 4.00$ & $47.89 \pm 3.0$ & $1.39 \pm 0.1$ & $81.22 \pm 14.7$ & $147.89 \pm 26.6$ & $9.67 \pm 1.41$ \\
\hline 1 & $105.20 \pm 5.7$ & $57.44 \pm 5.01$ & $47.80 \pm 6.3$ & $1.59 \pm 0.4$ & $65.89 \pm 15.1$ & $128.33 \pm 20.1$ & $12.33 \pm 2.09$ \\
\hline \multicolumn{8}{|l|}{ Interactions: } \\
\hline $\mathrm{T} 1(0 \mathrm{Cu} \times 0 \mathrm{An})$ & $106.23 \pm 20.3$ & $46.00^{c} \pm 0.00$ & $60.23 \pm 20.3$ & $0.96^{\mathrm{b}} \pm 0.3$ & $32.67 \pm 6.01$ & $173.00 \pm 12.1$ & $10.33 \pm 1.45$ \\
\hline $\mathrm{T} 2(0 \mathrm{Cu} \times 0.5 \% \mathrm{An})$ & $116.67 \pm 9.2$ & $69.33^{\mathrm{abc}} \pm 11.8$ & $47.33 \pm 2.9$ & $1.51^{\mathrm{ab}} \pm 0.3$ & $73.00 \pm 27.4$ & $171.67 \pm 24.2$ & $7.33 \pm 0.88$ \\
\hline $\mathrm{T} 3(0 \mathrm{Cu} \times 1 \% \mathrm{An})$ & $107.67 \pm 4.0$ & $52.33^{\mathrm{bc}} \pm 8.4$ & $55.33 \pm 4.7$ & $0.99^{\mathrm{b}} \pm 0.2$ & $75.00 \pm 44.0$ & $135.67 \pm 58.9$ & $11.33 \pm 5.84$ \\
\hline $\mathrm{T} 4(50 \mathrm{Cu} \times 0 \mathrm{An})$ & $111.33 \pm 4.1$ & $46.67^{\mathrm{c}} \pm 13.8$ & $64.67 \pm 13.3$ & $0.88^{\mathrm{b}} \pm 0.4$ & $74.33 \pm 15.3$ & $210.00 \pm 39.0$ & $8.00 \pm 1.73$ \\
\hline $\mathrm{T} 5(50 \mathrm{Cu} \times 0.5 \% \mathrm{An})$ & $118.00 \pm 4.0$ & $62.67^{\mathrm{abc}} \pm 4$ & $55.33 \pm 0.6$ & $1.14^{\mathrm{ab}} \pm 0.1$ & $57.67 \pm 19.6$ & $117.33 \pm 61.7$ & $10.33 \pm 3.18$ \\
\hline $\mathrm{T} 6(50 \mathrm{Cu} \times 1 \% \mathrm{An})$ & $112.00 \pm 11.9$ & $72.67^{\mathrm{ab}} \pm 6.9$ & $39.33 \pm 15.0$ & $2.57^{\mathrm{a}} \pm 0.9$ & $73.33 \pm 22.3$ & $120.67 \pm 26.4$ & $14.00 \pm 1.15$ \\
\hline T7 (100 Cu×0An) & $115.67 \pm 5.3$ & $82.67^{\mathrm{a}} \pm 1.45$ & $33.00 \pm 4.0$ & $2.58^{\mathrm{a}} \pm 0.3$ & $67.67 \pm 20.2$ & $169.67 \pm 69.5$ & $9.00 \pm 3.06$ \\
\hline $\mathrm{T} 8(100 \mathrm{Cu} \times 0.5 \% \mathrm{An})$ & $99.67 \pm 7.69$ & $58.67^{\mathrm{bc}} \pm 0.8$ & $41.00 \pm 7.0$ & $1.52^{\mathrm{ab}} \pm 0.2$ & $113.00 \pm 25.2$ & $154.67 \pm 57.83$ & $11.33 \pm 2.96$ \\
\hline T9 (100 Cu×1\%An) & $96.07 \pm 13.05$ & $47.33^{\mathrm{c}} \pm 1.45$ & $48.73 \pm 13$ & $1.20^{\mathrm{ab}} \pm 0$ & $49.33 \pm 10.6$ & $128.67 \pm 25.2$ & $11.67 \pm 3.84$ \\
\hline
\end{tabular}


Metwally et al.

Table (5): Effect of curcumin and anise seeds and their interactions on some blood parameters measured at age 42 day.

\begin{tabular}{|c|c|c|c|c|c|c|c|}
\hline Item & $\begin{array}{c}\text { Total protein } \\
(\mathrm{g} / \mathrm{dI})\end{array}$ & $\begin{array}{c}\text { Albumin } \\
(\mathrm{g} / \mathrm{dI})\end{array}$ & $\begin{array}{c}\text { Globulin } \\
(\mathrm{g} / \mathrm{dI})\end{array}$ & $\mathrm{A} \backslash \mathrm{G}$ & Calcium (mg/dI) & $\begin{array}{c}\text { Phosphorus } \\
(\mathrm{mg} / \mathrm{dI})\end{array}$ & $\begin{array}{c}\text { Uric acid } \\
(\mathrm{mg} / \mathrm{dI})\end{array}$ \\
\hline \multicolumn{8}{|l|}{ Curcumin (mg /Kg): } \\
\hline 0 & $3.79 \pm 0.09$ & $2.19 \pm 0.07$ & $1.60 \pm 0.0$ & $1.40 \pm 0.0$ & $8.79 \pm 0.31$ & $4.76 \pm 0.12$ & $4.41 \pm 0.3$ \\
\hline 50 & $3.54 \pm 0.11$ & $2.07 \pm 0.03$ & $1.48 \pm 0.1$ & $1.48 \pm 0.1$ & $8.63 \pm 0.43$ & $4.78 \pm 0.09$ & $4.07 \pm 0.1$ \\
\hline 100 & $3.71 \pm 0.09$ & $2.10 \pm 0.05$ & $1.61 \pm 0.1$ & $1.34 \pm 0.1$ & $8.39 \pm 0.28$ & $4.74 \pm 0.18$ & $4.29 \pm 0.1$ \\
\hline \multicolumn{8}{|l|}{ Anise seeds \%: } \\
\hline 0 & $3.67 \pm 0.13$ & $2.18 \pm 0.06$ & $1.49 \pm 0.1$ & $1.52 \pm 0.1$ & $8.06 \pm 0.26$ & $4.76 \pm 0.11$ & $4.00 \pm 0.1$ \\
\hline 0.5 & $3.71 \pm 0.09$ & $2.11 \pm 0.04$ & $1.60 \pm 0.1$ & $1.36 \pm 0.1$ & $8.99 \pm 0.40$ & $4.70 \pm 0.12$ & $4.49 \pm 0.2$ \\
\hline 1 & $3.67 \pm 0.10$ & $2.07 \pm 0.05$ & $1.60 \pm 0.1$ & $1.34 \pm 0.1$ & $8.77 \pm 0.28$ & $4.82 \pm 0.15$ & $4.26 \pm 0.1$ \\
\hline \multicolumn{8}{|l|}{ Interactions: } \\
\hline $\mathrm{T} 1(0 \mathrm{Cu} \times 0 \mathrm{An})$ & $3.97^{\mathrm{a}} \pm 0.1$ & $2.40^{\mathrm{a}} \pm 0.0$ & $1.57 \pm 0.1$ & $1.55 \pm 0.1$ & $8.07^{\mathrm{b}} \pm 0.2$ & $4.93 \pm 0.18$ & $3.73 \pm 0.4$ \\
\hline $\mathrm{T} 2(0 \mathrm{Cu} \times 0.5 \% \mathrm{An})$ & $3.80^{\mathrm{ab}} \pm 0.2$ & $2.20^{\mathrm{ab}} \pm 0.0$ & $1.60 \pm 0.2$ & $1.43 \pm 0.2$ & $9.93^{\mathrm{a}} \pm 0.0$ & $4.80 \pm 0.29$ & $4.90 \pm 0.6$ \\
\hline $\mathrm{T} 3(0 \mathrm{Cu} \times 1 \% \mathrm{An})$ & $3.60^{\mathrm{ab}} \pm 0.1$ & $1.97^{\mathrm{b}} \pm 0.03$ & $1.63 \pm 0.12$ & $1.22 \pm 0.11$ & $8.37^{\mathrm{ab}} \pm 0.24$ & $4.53 \pm 0.09$ & $4.60 \pm 0.2$ \\
\hline $\mathrm{T} 4(50 \mathrm{Cu} \times 0 \mathrm{An})$ & $3.27^{\mathrm{b}} \pm 0.1$ & $2.07^{\mathrm{b}} \pm 0.03$ & $1.20 \pm 0.15$ & $1.77 \pm 0.19$ & $7.63^{\mathrm{b}} \pm 0.41$ & $4.87 \pm 0.20$ & $3.97 \pm 0.1$ \\
\hline $\mathrm{T} 5(50 \mathrm{Cu} \times 0.5 \% \mathrm{An})$ & $3.53^{\mathrm{ab}} \pm 0.1$ & $2.03^{\mathrm{b}} \pm 0.03$ & $1.50 \pm 0.12$ & $1.37 \pm 0.11$ & $8.90^{\mathrm{ab}} \pm 0.85$ & $4.67 \pm 0.15$ & $4.17 \pm 0.5$ \\
\hline $\mathrm{T} 6(50 \mathrm{Cu} \times 1 \% \mathrm{An})$ & $3.83^{\mathrm{a}} \pm 0.1$ & $2.10^{\mathrm{b}} \pm 0.10$ & $1.73 \pm 0.27$ & $1.31 \pm 0.31$ & $9.37^{\mathrm{ab}} \pm 0.71$ & $4.80 \pm 0.12$ & $4.07 \pm 0.2$ \\
\hline T7 $(100 \mathrm{Cu} \times 0 \mathrm{An})$ & $3.77^{\mathrm{ab}} \pm 0.1$ & $2.07^{\mathrm{b}} \pm 0.07$ & $1.70 \pm 0.15$ & $1.24 \pm 0.12$ & $8.47^{\mathrm{ab}} \pm 0.64$ & $4.47 \pm 0.12$ & $4.40 \pm 0.3$ \\
\hline $\mathrm{T} 8(100 \mathrm{Cu} \times 0.5 \% \mathrm{An})$ & $3.80^{\mathrm{ab}} \pm 0.1$ & $2.10^{\mathrm{b}} \pm 0.10$ & $1.70 \pm 0.17$ & $1.27 \pm 0.18$ & $8.13^{\mathrm{b}} \pm 0.64$ & $4.63 \pm 0.26$ & $4.40 \pm 0.6$ \\
\hline T9 (100 Cu×1\%An) & $3.57^{\mathrm{ab}} \pm 0.2$ & $2.13^{\mathrm{b}} \pm 0.1$ & $1.43 \pm 0.1$ & $1.50 \pm 0.0$ & $8.57^{\mathrm{ab}} \pm 0.2$ & $5.13 \pm 0.41$ & $4.10 \pm 0.3$ \\
\hline
\end{tabular}


Table (5): Cont.

\begin{tabular}{|c|c|c|c|c|c|c|c|}
\hline Item & Cholesterol (mg/dI) & $\begin{array}{c}\text { HDL } \\
(\mathrm{mg} / \mathrm{dI})\end{array}$ & $\begin{array}{c}\text { LDL } \\
(\mathrm{mg} / \mathrm{dI})\end{array}$ & HDL/LDL & $\begin{array}{c}\text { Triglycerides } \\
(\mathrm{mg} / \mathrm{dI})\end{array}$ & $\begin{array}{l}\text { AST } \\
(\mathrm{u} / \mathrm{l})\end{array}$ & $\begin{array}{l}\text { ALT } \\
(\mathrm{u} / \mathrm{l})\end{array}$ \\
\hline \multicolumn{8}{|l|}{ Curcumin $(\mathrm{mg} / \mathrm{Kg})$ : } \\
\hline 0 & $145.60^{\mathrm{a}} \pm 7.61$ & $58.33 \pm 3.95$ & $87.22^{\mathrm{a}} \pm 6.28$ & $0.69^{b} \pm 0.05$ & $143.80 \pm 8.6$ & $213.60 \pm 12.19$ & $7.57 \pm 0.50$ \\
\hline 50 & $112.10^{\mathrm{b}} \pm 7.32$ & $53.56 \pm 3.92$ & $58.56^{\mathrm{b}} \pm 6.11$ & $1.00^{\mathrm{ab}} \pm 0.12$ & $130.70 \pm 12.1$ & $190.90 \pm 16.80$ & $9.60 \pm 0.88$ \\
\hline 100 & $112.80^{\mathrm{b}} \pm 3.74$ & $58.78 \pm 4.80$ & $54.00^{\mathrm{b}} \pm 4.41$ & $1.20^{\mathrm{a}} \pm 0.19$ & $139.40 \pm 9.5$ & $179.50 \pm 11.40$ & $8.23 \pm 0.59$ \\
\hline \multicolumn{8}{|l|}{ Anise seeds \%: } \\
\hline 0 & $123.10 \pm 6.60$ & $61.00 \pm 2.67$ & $62.11 \pm 6.33$ & $1.09 \pm 0.14$ & $122.00 \pm 10.5$ & $203.60 \pm 12.35$ & $9.01 \pm 0.70$ \\
\hline 0.5 & $130.40 \pm 11.02$ & $55.00 \pm 5.32$ & $75.44 \pm 9.22$ & $0.81 \pm 0.11$ & $149.80 \pm 9.9$ & $187.9 \pm 16.60$ & $7.78 \pm 0.70$ \\
\hline 1 & $116.90 \pm 6.35$ & $54.67 \pm 4.19$ & $62.22 \pm 6.13$ & $1.00 \pm 0.18$ & $142.10 \pm 7.92$ & $192.4 \pm 13.84$ & $8.61 \pm 0.75$ \\
\hline \multicolumn{8}{|l|}{ Interactions: } \\
\hline $\begin{array}{l}\text { T1 }(0 \mathrm{Cu} \times 0 \mathrm{An}) \\
\text { T2 }(0 \mathrm{Cu} \times 0.5 \% \mathrm{An}) \\
\text { T3 }(0 \mathrm{Cu} \times 1 \% \mathrm{An}) \\
\text { T4 }(50 \mathrm{Cu} \times 0 \mathrm{An}) \\
\text { T5 }(50 \mathrm{Cu} \times 0.5 \% \mathrm{An}) \\
\text { T6 }(50 \mathrm{Cu} \times 1 \% \mathrm{An}) \\
\text { T7 }(100 \mathrm{Cu} \times 0 \mathrm{An}) \\
\text { T8 }(100 \mathrm{Cu} \times 0.5 \% \mathrm{An}) \\
\text { T9 }(100 \mathrm{Cu} \times 1 \% \mathrm{An})\end{array}$ & $\begin{array}{c}139.70^{\mathrm{ab}} \pm 12.2 \\
167.30^{\mathrm{a}} \pm 10.1 \\
129.70^{\mathrm{b}} \pm 7.75 \\
113.70^{\mathrm{b}} \pm 11.4 \\
112.00^{\mathrm{b}} \pm 15.8 \\
110.70^{\mathrm{b}} \pm 16.0 \\
116.00^{\mathrm{b}} \pm 5.77 \\
112.00^{\mathrm{b}} \pm 9.02 \\
110.30^{\mathrm{b}} \pm 6.69\end{array}$ & $\begin{array}{c}61.00 \pm 6.66 \\
60.00 \pm 11.02 \\
54.00 \pm 2.65 \\
58.67 \pm 1.45 \\
48.67 \pm 10.20 \\
53.33 \pm 7.31 \\
63.33 \pm 5.78 \\
56.33 \pm 8.97 \\
56.67 \pm 12.14\end{array}$ & $\begin{array}{c}78.67^{\mathrm{b}} \pm 5.78 \\
107.30^{\mathrm{a}} \pm 10.4 \\
75.67^{\mathrm{b}} \pm 5.18 \\
55.00^{\mathrm{b}} \pm 11.7 \\
63.33^{\mathrm{b}} \pm 9.70 \\
57.33^{\mathrm{b}} \pm 14.0 \\
52.67^{\mathrm{b}} \pm 10.1 \\
55.67^{\mathrm{b}} \pm 6.36 \\
53.67^{\mathrm{b}} \pm 9.33\end{array}$ & $\begin{array}{l}0.77 \pm 0.04 \\
0.58 \pm 0.13 \\
0.72 \pm 0.02 \\
1.17 \pm 0.26 \\
0.79 \pm 0.15 \\
1.02 \pm 0.23 \\
1.32 \pm 0.30 \\
1.06 \pm 0.23 \\
1.23 \pm 0.50\end{array}$ & $\begin{array}{c}149.70 \pm 13.3 \\
151.70 \pm 13.1 \\
130.00 \pm 19.9 \\
104.30 \pm 19.7 \\
139.30 \pm 24.9 \\
148.30 \pm 14.4 \\
112.00 \pm 13.2 \\
158.30 \pm 17.2 \\
148.00 \pm 6.0\end{array}$ & $\begin{array}{c}228.19 \pm .92 \\
196.30 \pm 32.6 \\
216.30 \pm 7.8 \\
205.00 \pm 28.02 \\
204.00 \pm 33.3 \\
163.70 \pm 30.6 \\
177.70 \pm 3.8 \\
163.30 \pm 25.7 \\
197.30 \pm 24.2\end{array}$ & $\begin{array}{c}7.70 \pm 0.85 \\
7.33 \pm 1.20 \\
7.67 \pm 0.88 \\
10.67 \pm 1.45 \\
7.67 \pm 1.16 \\
10.17 \pm 1.97 \\
8.67 \pm 0.88 \\
8.03 \pm 1.70 \\
8.00 \pm 0.58\end{array}$ \\
\hline
\end{tabular}




\section{CONCLUSION}

It was recommended that curcumin should be added at level of 100 or $50 \mathrm{mg} / \mathrm{kg}$ diet curcumin plus $1 \%$ anise ground seeds to achieve higher performance, blood parameters of broiler chicken (Ross 308).

\section{REFERENCES}

ACSAD (2012). Arab Center for the Studies of Arid Zones and Arid Lands. Atlas of Medicinal and Aromatic Plants in the Arab World.

Albokhadaim, I.; Althnaian, Thnaian and S. M. El-Bahr,(2012). Investigation of selected biochemical parameters of local chickens with different age and sex in Al-ansa, Saudi Arabia. Pakistan Journal of Biological Sciences, 15 (17), 827-832.

AL-Zuhairi, Z. A. and Afrah S. AL-Tabari (2013). Effect the addition of Anis seed (Pimpinella anisum L.) powder on production performance and some blood and biochemical parameters in broiler chickens. Kufa journal for veterinary medical sciences, 4,(2):12-20.

Amein, S. M.; G. M. M. Mosaad and M. K. Hussein (2019). Effect of some medicinal plants as feed additives on growth performance, blood constituents and carcass characteristics of broilers. J. Adv. Vet. Res., 9 (4): 170-177.

AOAC (1990). Association of Official Analytical Chemists.Official.Methods of Analysis (13 ${ }^{\text {th }}$ Ed) Washington, DC, USA.

Badran, A.M. M.; H. A. Basuony; M. A. Elsayed and A. E. Abdel-Moneim (2020). Effect of dietary curcumin and curcumin nanoparticles supplementation on growth performance, immune response and anti-oxidant of broilers chickens. Egypt. Poult. Sci., 40:325-343.

Barakat, D.M.; A. H. El-Far1; K. M. Sadek; U. E. Mahrous; H. F. Ellakany and Mervat A. Abdel-Latif (2016). Anise (Pimpinella anisum) enhances the growth performance, immunity and antioxidant activities in broilers. Int. J. Pharm. Sci. Res., 37(2): 134-140

Candra. A.A. and D. Putri (2020). Application turmeric as antioxidant for broiler chickens. Journal of Physics: Conference Series.10.1088/1742-6596.

Cifftci, M.; T. Guler; B. Dalkilic and ON. Ertas (2005). The effect of anise oil (Pimpinella anisum L.) on broiler performance. Int. J. Poult. Sci., 4(11):851-855.

Dalal, R. and D. kosti (2018). Turmeric powder as feed additive in laying hen A-review. Journal of Pharmacognosy and Phytochemistry, 7 (3): 2686-2689.

Duncan, D.B. (1955). Multiple range and multiple F tests. Biometrics, 11: 1-42.

Fotina, A. A.; V. I. Fisinin and P. F. Surai (2013). Recent developments in usage of natural antioxidants to improve chicken meat production and quality. Bulgarian J Agri. Sci., 19:889-896.

Gabriela M. G.; L.G. Griss; M. M. Boiago; T. Petrolli, P. G. Bianca; B. P. Copettid; A. Da Silva; M. Schetinger; L. Sareta; R. Mendes; J. Mesadri; R. Wagner; S. Gundelg; A. Ourique; A. Da Silva (2020). Effects of curcumin and yucca extract addition in feed of broilers on microorganism control (anticoccidial and antibacterial), health, performance and meat quality. Journal Pre-proof S00345288(20)30488-4.

Jabbar.T. A.A.; Iqbal I.Saleh and Iman Abdul- Rahman (2015). Effect of supplementation different levels of (Pimpinella anisum) on the productive performance and some blood biochemical parameters of broiler chicken.Basrah J. Agric. Sci., 28 (1):128-141. 
Kang, J. H.; T. Goto; I. S. Han; T. Kawada; Y. M. KimRina Yu1 (2010). Dietary capsaicin reduces obesity-induced insulin resistance and hepatic steatosis in obese mice fed a high-fat diet. Obesity Silver Spring, 4: 780-787.

Khan, R.U.; S. Naz; M. Javdani; Z. Nikousefat; M. Selvaggi; V. Tufarelli and V. Laudadio ( 2012). The use of turmeric (Curcuma longa) in poultry feed. World's Poultry Science Journal, Vol. (68):97-103.

Mahmod .A. Z. M (2013). Response of broiler chicks to Ration containing different levels of anise seeds powder as natural feed additive.(Master dissertation, of University of Sudan).

Mohammed, H.N. (2019). Broiler performance response to anise seed powder supplementation.Iraqi Journal of Veterinary Sciences, 33:131-135

Motlaq .A. M. and H. L. Sadik (2012).Effect of supplementing different combination levels of crushed Seeds of fenugreek and anise to the diets on productive performance of broiler. Anbar Journal of Veterinary Sciences, 5(2) :1999-6527.

NRC (1994). National Research council. Nutrient Requirements of Poultry. Ninth Revised Edition, National Academy Press. Washington, DC, USA.

Perić, L.; D. Žiki ć and M. Luki ć (2009). Application of alternative growth promoters in broiler production. Biotechnol Anim. Husb., 25:387-397

Prasad, S.; A. K. Tyagi and B. B. Aggarwal (2014). Recent developments in delivery, bioavailability, absorption and metabolism of curcumin: the golden pigment from golden spice. Cancer Research and Treatment, 46: 2-18.

Qasem, M. A. A.; M. S. Alhajj; A.R. Jer El Nabi and S.I. Al-Mufarrej (2016). Effects of dietary supplement of turmeric powder (Curcuma longa) on blood biochemistry parameters and antioxidant activity in chickens.S. Afr. J. Anim. Sci., 46(2):206-213.

Rajput, N; N. Muhammah; R. Yan; X. Zhong and T. Wang (2012). Effect of dietary supplementation of curcumin on growth performance, Intestinal morphology and nutrients utilization of broiler chicks. The Journal of Poultry Science, 10.2141/jpsa.0120065.

SAS (2006). SAS Users Guide Statistics Version 10th, 16- Edition, SAS Inst., Cary, NC.

Soltan, M. A.; R. S. Shewita and M. I. El-Katcha (2008). Effect of dietary anise seeds supplementation on growth performance, immune response, carcass traits and some blood parameters of broiler chickens. International Journal of Poultry Science, 7 (11): 1078-1088.

Suganya, T.; S. Senthilkumar; K. Deepa; J. Muralidharan; G. Gomathi and S. Gobiraju (2016). Herbal feed additives in poultry. Int. J Sci. Env. Technol., 5:1137-1145.

Tipu, M.A.; T. N. Pasha and Z. Ali (2002). Comparative efficacy of salinomycin sodium and Noni fruit (Aidiacht indica) as feed additive anticoccidials in broilers. Int. J. Poult. Stud., 1(4): 91-93.

Xie, Z.; G. Shen; Y. Wang and C. Wu (2019). Physiology and reproduction curcumin supplementation regulates lipid metabolism in broiler chickens. Poultry Science, 98:422-429. 
تأثير اضافة بعض الأعشاب الطبية او مستخلصاتها على الاداء والوظائف الفسيولوجية في كتاكيت اللحم. 1-تأثير الكركمين و بذور الينسون المطحون والتداخل بينهما على معدل أداء كتاكيت اللحم وبعض مقاييس الدام

محمل متولى أحمد1، نادى محم عيسى و أحمد محمود الهادي2

2قام انتاج الدواجن ـ كليه الزراعة - جامعه أسيوط - مصر.

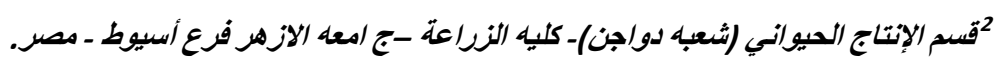

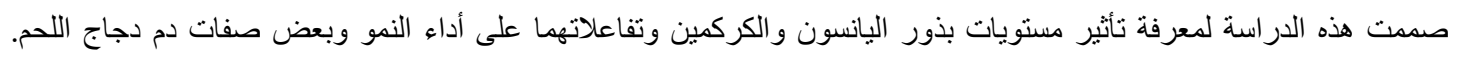

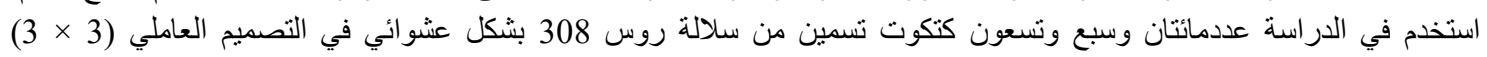

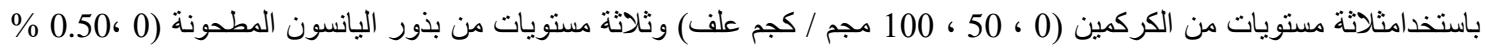

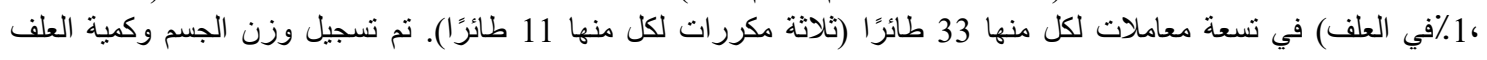

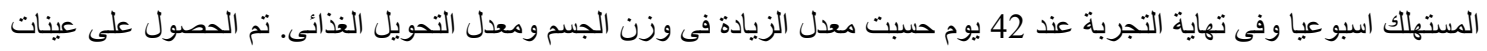

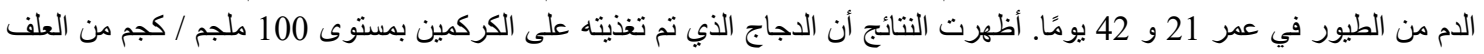

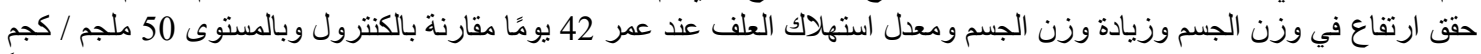

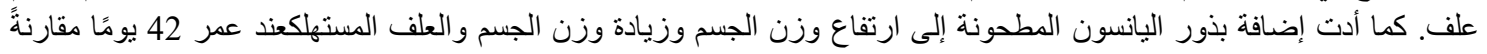

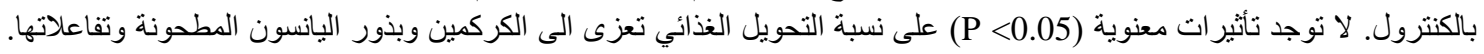

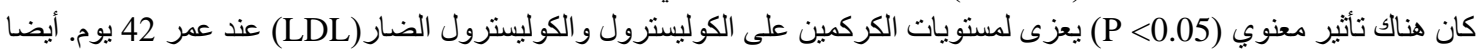

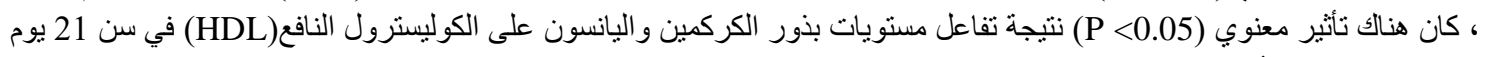

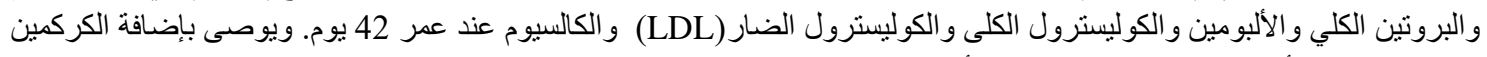

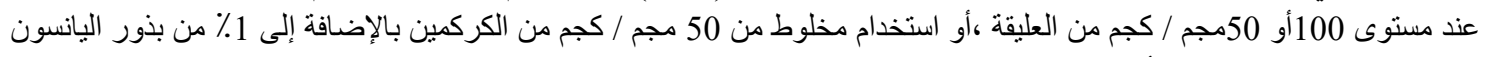

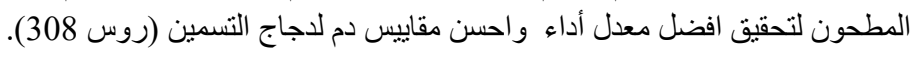

